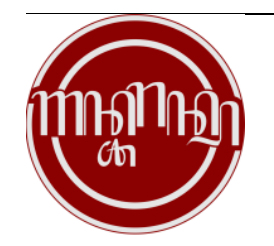

\title{
GHÂNCARAN: JURNAL PENDIDIKAN BAHASA DAN SASTRA INDONESIA
}

http://ejournal.iainmadura.ac.id/index.php/ghancaran E-ISSN : 2715-9132 ; P-ISSN: 2714-8955 DOI 10.19105/ghancaran.vi.5310

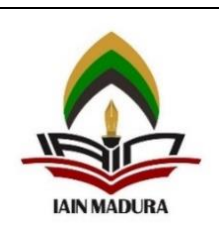

\section{Integrasi Aspek Afektif melalui Pembelajaran Bahasa Indonesia Berbasis Teks Muatan Kearifan Lokal untuk Membangun Karakter Siswa Sekolah Dasar Pascapandemi Covid-19}

\author{
Nur Samsiyah*, Endang Sri Maruti**, Ririn Nuryanti** \\ * Pendidikan Guru Sekolah Dasar, Universitas PGRI Madiun \\ ** Pendidikan Guru Sekolah Dasar, Universitas PGRI Madiun \\ *** SDN Taman 01 Madiun
}

Alamat surel: nursamsiyah@unipma.ac.id/nurssya08@gmail.com

\begin{tabular}{|c|c|}
\hline & Abstract \\
\hline \multirow[t]{2}{*}{$\begin{array}{l}\text { Keywords: } \\
\text { Affective; } \\
\text { Learning; } \\
\text { Local } \\
\text { Wisdom; } \\
\text { Caracter }\end{array}$} & $\begin{array}{l}\text { Indonesian language learning is the parent of science, so it must } \\
\text { be carried out oriented to the formation of language skills and other } \\
\text { sciences. The success of learning Indonesian cannot be separated } \\
\text { from the role of the teacher in teaching activities in developing } \\
\text { students' potential so that their cognitive and affective } \\
\text { developments. One of the ways in which language learning is } \\
\text { developed is through dignified learning that reflects the existence of } \\
\text { cultural values and norms. Values and culture can be taught by } \\
\text { integrating affective aspects of Indonesian language learning by } \\
\text { utilizing texts containing regional cultures that exist around } \\
\text { students. The use of texts containing local wisdom serves } \\
\text { tointroduce local culture so that it can be preserved and develop a } \\
\text { caring and proud character of ancestral heritage. Various kinds of } \\
\text { texts containing local wisdom such as texts on the theme of art, } \\
\text { customs, mutual cooperation activities, traditional food and other } \\
\text { regional cultures. }\end{array}$ \\
\hline & Abstrak: \\
\hline $\begin{array}{l}\text { Kata Kunci: } \\
\text { Afektif; } \\
\text { Pembelajaran } \\
\text { bahasa Indonesia; } \\
\text { Kearifan lokal; } \\
\text { Karakter }\end{array}$ & $\begin{array}{l}\text { Pembelajaran bahasa Indonesia menjadi induk ilmu pengetahuan, } \\
\text { sehingga harus dilakssiswaan berorientasi pada pada } \\
\text { pembentukan kemampuan berbahasa dan keilmuan lain. } \\
\text { Keberhasilan pembelajaran bahasa Indonesia tidak lepas dari } \\
\text { peran guru dalam kegiatan mengajar dalam mengembangkan } \\
\text { potensi siswa agar kognitif dan afektifnya berkembang. } \\
\text { Pembelajaran bahasa salah satunya dikembangkan melalui } \\
\text { pembelajaran yang bermartabat yang mencerminkan adanya nilai - } \\
\text { nilai dan norma budaya. Nilai dan budaya dapat diajarkan dengan } \\
\text { menintegrasikan aspek afektif pembelajaran bahasa Indonesia } \\
\text { dengan memanfaatkan teks bermuata budaya daerah yang ada di } \\
\text { sekitar siswa. Pemanfaatan teks bermuatan kearifan lokal berfungsi } \\
\text { untuk mengenalkan budaya daerah agar dapat dilestarikan dan } \\
\text { mengembangkan karakter peduli dan bangga pada warisan leluhur. } \\
\text { Berbagai macam teks bermuatan kearifan lokal seperti teks } \\
\text { bertema kesenian, adat istiadat, kegiatan gotong royong, makanan } \\
\text { tradisional dan budaya daerah lainnya. }\end{array}$ \\
\hline
\end{tabular}
; Diterima: 01-11-2021 
Nur Samsiyah, Endang Sri Maruti, dan Ririn Nuryanti

\section{PENDAHULUAN}

Hasil belajar memiliki tiga domain, kognitif, afektif dan psikomotor. Ranah afektif sendiri didasarkan pada UU no 20 tahun 2003 yang menjelaskan bahwa sistem pendidikan harus mewujudkan masyarakat berakhlak mulia, bermoral, memiliki etika, berbudaya dan beradab. Tahapan ranah afektif dimulai dari menerima, merespon, menghargai, mengatur dan berkarakter (Thomas, 2004). Dalam lima tahapan tersebut mencakup perasaan, semngat, menghargai, nilai, motivasi yang harus diwujudkan dalam kehidupan siswa. Oleh karena itu pendidikan dalam ranah afektif sangat penting untuk menanamkan karakter baik agar menjadi kebiasaan siswa. Penelitian (Mungmachon, 2012) di sebuah desa kecil di Thailand menunjukkan keterpaparan pada institusi akademik dan media massa merupakan faktor utama yang membuat penduduk desa melihat diri mereka sendiri sebagai orang tua bergaya dan tidak beradab, dan mengabaikan pengetahuan dan kebijaksanaan berharga di masa lalu. Tidak dapat dipungkiri bahwa kebiasaan buruk orang tua akan berpengaruh terhadap anaknya. pengaruh tersebut juga menyebabkan orang kehilangan pengetahuan dan kearifan tradisional sehingga berdampak negatif pada karakter siswa. Karena ranah afektif memiliki kaitan dengan sikap dan nilai. Sikap merupakan refleksi dari nilai (Sanjaya, 2010). Sejalan dengan Sanjaya, (Lickona, 2009) menjelaskan bentuk nilai yang sebaiknya diajarkan di sekolah adalah kejujuran, keadilan, toleransi, kebijaksanaan, disiplin, tolong menolong, kerjasama, keberanian dan demokratis. Atas dasar tersebut aspek afektif tidak hanya diajarkan sebagai bagian dari hasil belajar saja, namun menjadi bagian terpenting untuk menanamkan karakter dalam proses pembelajaran terlebih dalam kondisi pandemi covid-19. Dalam praktiknya pendidikan karakter tidak semudah membalikkan tangan apalagi di masa pandemi yang mana pelaksanaan pembelajaran masih dilakukan secara daring melalui aplikasi pembelajaran atau tugastugas. Sehingga diperlukan pembelajaran yang menuntut siswa lebih aktif dan kreatif tanpa mengesampingkan masalah moral dan etika.

Permasalahan moral dan etika tidak hanya terjadi pada orang dewasa. Berdasarkan catatan tahunan komnas perempuan selama masa pandemi angka kekerasan dapat dilihat semakin meningkat terlebih kekerasan pada perempuan mulai dari balita sampai orang tua. Belum lagi ditambah dengan masalah pembelajaran yang dilakssiswaan selama pandemi lebih banyak memberikan tugas melalui wathsapp group (Syamsiyah, 2020). Maka tidak heran jika kasus kekerasan dan pelecehan terhadap siswa semakin meningkat. Jika dilihat dari kondisi siswa yang mengerjakan tugas setiap hari tanpa pendampingan orang tua, secara otomatis siswa akan melihat 
dan menggantungkan jawaban pada google. Siswa akan lebih mudah mengerjakan tanpa bantuan orang tua jika ada hanphone yang sudah terisi data internet dan tugas akan lebih cepat selesai sehingga siswa akan lebih cepat bermain game online maupun offline. Apabila pembelajaran masih menggunakan tugas dan dikirim melalui wathsapp group atau pribadi maka karakter siswa cenderung lebih menyukai tugas daripada belajar secara langsung. Sehingga pembelajaran budi pekerti agar karakter siswa muncul sangat kurang dalam masa belajar di rumah. Karena tujuan pokok pendidikan budi pekerti adalah pembentukan watak, kepribadian, dan perilaku. Berdasarkan pendapat Jarolimek, pendidikan budi pekerti dapat disamakan dengan pendidikan karakter dan termasuk ke dalam pendidikan afektif, (Jarolimek, 1964). Oleh karena itu pendidikan budi pekerti lebih kepada domain afektif yang didukung oleh domain kognitif dan psikomotor. Siswa -siswa perlu diberikan bimbingan dan penanaman kebiasaan baik di rumah maupun di sekolah. Karena kondisi pandemi maka keluarga menjadi tempat utama bagi siswa untuk belajar dan menerima pendidikan akademik dan nonakademik terlebih pendidikan karakter. Meskipun pembelajaran lebih banyak dilakukan di rumah namun guru perlu memberikan motivasi agar siswa tetap dapat melaksanakan tugas dengan tetap membangun karakter baik dalam diri siswa. Guru harus dapat membatu membelajarkan siswa dengan berpegang teguh pada nila-nilai yang dimiliki (Sjarkawi, 2020). Untuk melakssiswaan pembelajaran dengan tetap membangun karakter siswa, salah satunya melalui integrasi aspek afektif dalam pembelajaran bahasa Indonesia.

Pembelajaran bahasa Indonesia menggambarkan sejumlah aktivitas siswa yang berguna untuk membentuk kemampuan berbahasa siswa. Menurut (Abidin, 2012) pembelajaran bahasa perlu dikembangkan menjadi (1) pembelajaran yang harmonis agar dapat merangksang guru dan siswa bekerja secara aktif sesuai tugas dan fungsinya, (2) pembelajaran yang bermutu untuk mencapai pembentukan kompetensi siswa yang berorientasi pada tujuan pembelajaran, (3) pembelajaran yang bermartabat yang mencerminkan nilai-nilai dan norma budaya. Pendidikan karakter yang dalam pembelajaran bahasa memiliki fungsi sebagai pembinaan karakter secara umum dan sebagai pembinaan berbahasa. Pembelajaran bahasa Indonesia yang dapat menginegrasi aspek afektif nilai dan budaya dapat dilakukan dengan teks yang bermuatan kearifan lokal. Kearifan lokal merupakan suatu sudut pandang manusia dengan menggunakan akal sehatnya untuk berperilaku terhadap sesuatu objek, atau peristiwa yang terjadi (Yusa \& Jayanegara, 2014). Kearifan lokal sangat menentukan harkat dan martabat manusia dalam suatau kelompok (Greertz, 2003). 
Nur Samsiyah, Endang Sri Maruti, dan Ririn Nuryanti

Dalam teks bermuatan kearifan lokal dapat diambil dari kisah atau sejarah yang muncul di daerah sekitar siswa. Salah satunya sejarah yang ada di Kota Madiun, yaitu kesenian solah mediunan, penthul tembem, masjid Kuno, bersih desa dan larung sesaji. Berbagai budaya tersebut perlu mendapat perhatian guru agar dapat diajarkan pada siswa dengan tujuan membangun karakter menghargai budaya dan ikut melestarikannya. Samsiyah (2019) menjelaskan bahwa kegiatan literasi yang dilaksanakan siswa dengan menginternalisasi budaya daerah dapat menanamkan karakter keteladanan, mencintai budaya daerah, religius dan kejujuran. Bagaimana integrasi aspek afektif dalam pembelajaran bahasa Indonesia melalui teks bermuatan kearifan lokal agar dapat membangun karakter siswa?.

\section{METODE}

Penelitian ini merupakan penelitian deksriptif. Penelitian ini ingin mengetahui integrasi aspek afektif dalam pembelajaran di sekolah dasar kelas 4. Penelitian dilakukan di SD Taman 01 Kota Madiun. Data diambil dari guru kelas 4, berupa dokumen materi pembelajaran tematik muatan bahasa Indonesia yang mengintegrasikan aspek afektif dalam teks bacaan bermuatan kearifan lokal di kota Madiun. Data dikumpulan dengan observasi kegiatan guru dan wawancara dalam mengintegrasikan aspek afektif melalui pembelajaran bahasa Indonesia. Data dikumpulkan dalam bentuk catatan lapangan tentang materi yang terintegrasi aspek afektif dalam teks bermuatan kearifan lokal.

\section{HASIL DAN PEMBAHASAN}

Integrasi aspek afektif dikembangkan dalam kurikulum 2013 yang ada dalam kompetensi inti 1 dan 2. Selain itu aspek afektif yang merupakan aspek sikap dikaitkan dengan penguatan pendidikan karkater seperti religi, rasa nasionalisme, integritas, kemandirian dan gotong royong. Dalam pembelajaran bahasa Indonesia aspek afektif dapat diciptakan dalam proses dengan berlandaskan pembelajaran yang aktif dan kreatif pada setiap pembelajaran membaca, menulis menyimak dan berbicara. Aspek afektif sebagai bagaian dari pendidikan karakter dapat diintegrasikan melalui semua mata pelajaran khususnya pembelajaran bahasa Indonesia.

Pada saat masa pembelajaran di rumah, guru dapat memberikan stimulus melalui video yang dikirim ke group kelas atau melalui aplikasi pembelajaran seperti microsoft time, google meet, zoom dan lainnya. Pembelajaran dengan menggunakan aplikasi tersebut dapat bertatap maya dengan siswa dan melihat perilaku siswa ketika mengikuti 
pembelajaran. dalam pembelajaran bahasa Indonesia aspek afektif dapat diinegrasikan ke dalam materi atau bahan ajar yang akan diberikan ke siswa, melalui model pembelajaran seperti diskusi, debat online, parafrase dan melalui penilaian autentik. Dalam materi teks yang disajikan sesuai kearifan lokal di daerah siswa, sedangkan model pembelajaran guru menggunakan diskusi dan kolaborasi agar siswa bisa berdiskusi secara online. Penilaian autentik dilakukan guru dengan meilihat keaktifan siswa selama pembelajaran, aktivitas dan sikap siswa dan hasil belajar membaca, menulis, berbicara dan menyimak yang menggunakan rubrik penilaian.

Dalam pembelajaran membaca terdapat ketercapaian dan penyusunan program pembelajaran membaca yang harus dilakukan oleh guru agar sesuai kebutuhan membaca siswa. Sehingga ketika kegiatan membaca dilakukan oleh siswa dengan menugaskan siswa membaca buku yang menarik judul dan isinya, diharapkan dapat menimbulkan perasaan senang membaca. Aspek afektif akan timbul rasa senang membaca pada bacaan. Secara umum pembelajaran membaca dilakukan dalam 3 tahapan, yaitu pra baca, tahap membaca dan pasca baca. Pada setiap tahapan terdapat aspek afektif yang dapat meningkatkan karakter siswa dalam setiap aktivitasnya. Berikut diuraikan aktivitas siswa dalam membaca sesuai dengan karakter yang muncul.

\begin{tabular}{lll}
\hline \multicolumn{1}{c}{ Aspek } & \multicolumn{1}{c}{ Kegiatan } & \multicolumn{1}{c}{ Karakter } \\
\hline Tahap Prabaca & $\begin{array}{l}\text { Curah pendapat, } \\
\text { mengidentifikasi jenis buku }\end{array}$ & Jujur \\
\hline Tahap membaca & $\begin{array}{l}\text { Membaca dengan teknik } \\
\text { skiming, scaning, membaca } \\
\text { sekilas, membaca dalam } \\
\text { hati, menemukan inti sari } \\
\text { atau ide pokok, membaca } \\
\text { intensif teks, }\end{array}$ & $\begin{array}{l}\text { Kerja keras, produktif, } \\
\text { ulet rajin }\end{array}$ \\
\hline Tahap pascabaca & $\begin{array}{l}\text { Parafrase, membuat mind } \\
\text { mapping teks bacaan, }\end{array}$ & $\begin{array}{l}\text { Jujur memnjawab } \\
\text { pertanyaan, }\end{array}$ \\
& $\begin{array}{l}\text { meringkas, membuat bagan } \\
\text { teks }\end{array}$ & $\begin{array}{l}\text { memprsentasikan } \\
\text { jawaban, kreatif dalam } \\
\text { parafrase dengan } \\
\text { bahasa atau kalimatnya } \\
\end{array}$ \\
& & sendiri \\
\hline
\end{tabular}

Tabel 1. Aktivitas membaca siswa berbasis karakter

Pada kegiatan pembelajaran membaca yang dilakukan oleh siswa mulai tahap prabaca sampai setelah selesai membaca terdapat aspek afektif yang dapat meningkatkan karakter siswa jika dilakukan setiap hari. Aspek afektif yang muncul dalam pembelajaran yaitu, curah pendapat yang dapat dilakukan dengan memberikan teks yang berisi kearifan lokal yang ada di daerahnya kemudian siswa diminta saling 
Nur Samsiyah, Endang Sri Maruti, dan Ririn Nuryanti

bertanya jawab tentang teks atau curah pendapat tentang teks yang sudah diberikan. Curah pendapat dapat memebrikan stimulus bagi siswa untuk jujur dalam berpendapat, menghargai pendpaat orang lain. Sedangkan tahap membaca akan muncul karakter kerja keras, produktif dan rajin. Hal ini dapat dilihat misalnya ketika siswa melakukan kegiatan membaca dalam hati untuk menentukan ide pokok atau gagasan, siswa harus bekerja keras untuk membaca dan memahami makna pada bacaan agar dapat menemukan ide pokok. Sedangkan tahap pascabaca aspek afektif akan muncul saat siswa bekerja keras membuat mind mapping dari teks bacaan yang telah dibacanya. Sehingga karakter yang muncul harus jujur dalam menjawab seluruh pertanyaan, kreatif dalam membuat mind mapping dan mempresentasikan atau menyajikan hasil dengan baik.

Aspek afektif dalam pembelajaran berbicara dilakukan dengan aktivitas-aktivitas berbicara mulai sebelum berbicara sampai setelah selasai berbicara. Kegiatan berbicara dapat dilakukan dengan metode berpidato, orasi ilmiah atau debat, bermain peran. Sebelum melakukan aktivitas, misalnya bermain peran, siswa perlu dikelompokkan menurut kelompoknya secara online dan memberikan bahan teks bacaan yang berisi percakapan tentang budaya atau kesenia yang ada di daerahnya untuk dipelajari. Setelah selesai mempelajari siswa dapat melakukan video call atau membuat video rekaman percakapan bersama kelompoknya. Begitu juga dengan kegiatan diskusi dapat dilakukan denga menggunakan aplikasi google meet atau zoom untuk memfasilitasi kegiatan berbicara siswa. Selama melaksanakan aktivitas berbicara siswa dituntut untuk jujur dalam berbicara, beretika, sopan dan terbuka. Guru melakukan penilaian autentik terhadap keterampilan berbicara siswa sehingga pembinaan karakter semakin kuat.

Pada pembelajaran menulis diarahkan untuk membina kemampuan menulis siswa. (Akhadiah, 1991) menjelaskan menulis sebagai proses penuangan gagasan ke dalam bahasa tulis yang praktiknya dilakukan dalam beberapa tahapan. Untuk menghasilkan tulisan yang baik agar siswa memiliki sikap tanggung jawab terhadap hasil tulisannya diperlukan sebuah proses sebelum menjadi tulisan utuh. Tomkins \& Hoskisson (1991) menjelaskan proses menulis menjadi lima tahap yaitu tahap pramneulis dapat dilakukan siswa dengan menentukan topik, tahap pembuatan draf dilakukan dengan mengembangkan topik menjadi kalimat, tahap editing, tahap revising dan tahap publikasi. Berikut ini tabel aktivitas dalam pembelajaran menulis beserta karakter yang dapat dibangun. 


\begin{tabular}{|c|c|c|}
\hline Aspek & Kegiatan & Karakter \\
\hline Tahap Pramenulis & $\begin{array}{l}\text { Memilih topik } \\
\text { Memilih judul tentang salah satu } \\
\text { budaya di daerahnya (misalkan tari } \\
\text { pentul thembem) } \\
\text { Mengumpulkan data tentang } \\
\text { kesenian tersebut baik dari online } \\
\text { maupun offline }\end{array}$ & $\begin{array}{l}\text { Sopan dalam bertanya ke } \\
\text { narasumber } \\
\text { Jujur dalam memilih }\end{array}$ \\
\hline Penyusunan draf & $\begin{array}{l}\text { Memilih kata kunci untuk membuat } \\
\text { kalimat } \\
\text { Menulis draf budaya daerah dari } \\
\text { data yang dikumpulkan }\end{array}$ & $\begin{array}{l}\text { Kerja keras, produktif, ulet } \\
\text { rajin }\end{array}$ \\
\hline Tahap revisi & $\begin{array}{l}\text { Menambah, mengganti dan } \\
\text { menghilangkan bahan tulisan yang } \\
\text { sudah dibuat dan memperbaiki } \\
\text { tulisan }\end{array}$ & Kerja keras \\
\hline Tahap editing & $\begin{array}{l}\text { Memperbaiki kesalahan dalam } \\
\text { tulisan seperti bahasa, ejaan } \\
\text { Menyesuaikan dengan format atau } \\
\text { sistematika tulisan }\end{array}$ & Rajin dan ulet \\
\hline Tahap publikasi & $\begin{array}{l}\text { Membacakan hasil tulisan dengan } \\
\text { mempresentasikan secara online, } \\
\text { mengunggah tulisan dalam akun } \\
\text { media, }\end{array}$ & Berani, jujur \\
\hline
\end{tabular}

\section{Tabel 2. Aktivitas pembelajaran menulis}

Berdasarkan tabel di atas, siswa dibiasakan menulis dari proses menentukan topik tentang budaya daerah sampai hasil tulisan yang siap dipublikasikan dalam jurnal sekolah, majalah dinding atau menggunakan teknologi seperti media sosial. Proses tersebut perlu mendapat bimbingan guru agar tulisan tidak menyebarkan hoaks jika diunggah dalam media sosial. Pada saat siswa mendapatkan bimbingan mulai pramenulis, aktivitas siswa akan memunculkan aspek afektif yang dapat membangun karakternya seperti teliti dalam memilih bacaan yang digunakan sebagai sumber, kritis, kerapian dalam menulis, terbuka dalam menerima informasi. Hal ini sejalan dengan pendapat (Abidin, 2012) yang menjelaskan bahwa saat siswa melakukan kegiatan ekplorasi, siswa sedang membiasakan diri untuk teliti, cermat, peka, antusias, kreatif dan disiplin.

Pembelajaran menyimak dilakukan untuk melatih konsentrasi atau daya ingat siswa. Pembelajaran menyimak tidak hanya dilakukan dengan menjawab pertanyaan dalam teks. hal ini sama saja dengan kegiatan membaca. Akan lebih baik jika pemahaman menyimak dilakukan dengan mendengarkan radio atau berita Karakter dapat dibangun dalam diri siswa dalam proses pembelajaran dilakukan dengan menggunakan teks satra yang berisi muatan kearifan lokal. Dalam teks sastra terdapat bacaan yang cerita dan dongeng berisi pesan atau amanat dan nilai-nilai 
moral dalam teks. Selain melalui bahan ajar pendidikan karakter dapat dilakukan dengan penilaian secara otentik oleh guru dan proses pembelajaran menggunakan model pembelajaran yang sesuai. Hal ini sejalan dengan pendapat Abidin (2015) yang menyatakan bahwa membina karakter dalam pembelajaran bahasa Indonesia dapat dilakukan dengan melalui (1) bahan ajar, (2) melalui penggunaan model pembelajaran, dan (3) melalui penilaian autentik.

\section{SIMPULAN}

Aspek afektif dapat diintegrasikan dalam pembelajaran di masa pascapandemi covid-19 dengan menerapkan materi ajar berbasis teks muatan kearifan lokal, seperti kesenian misalnya penthul tembem, solah mediunan, budaya larung sesaji dan makanan khas di daerah sekitar siswa. Tujuannya untuk menanamkan karakter menghargai budaya, mengenal budaya daerahnya dan ikut melestarikan budaya daerahnya. Karakter dapat dibangun dalam diri siswa dalam proses pembelajaran melalui penggunaan model pembelajaran dengan aplikasi google meet atau zoom dengan mengajak siswa berdiskusi, curah pendapat, kolaborasi dan (3) melalui penilaian autentik.

\section{UCAPAN TERIMA KASIH (OPSIONAL)}

Terimakasih kepada Kepala sekolah SDN Taman 01 Kota Madiun, yang selalu siap menerima dan membantu dalam penelitian.

\section{DAFTAR RUJUKAN}

Abidin, Y. (2012). Pembelajaran bahasa berbasis pendidikan karakter. Refika Aditama. Akhadiah, S. (n.d.). dkk. 1991. Pembinaan Kemampuan Menulis Bahasa Indonesia. Greertz, C. (2003). Pengetahuan Lokal (penerjemah: Mubaikah, V., dan Danarto, A., dari Local Knowledge: Further Essays in Interpretative Anthrophology). Yogyakarta: Merapi.

Jarolimek, J. (1964). Social Studies in Elementary Education Second Edition 2nd ed. The Macmillan Company.

Komnas Perempuan. (2020). CATAHU 2020: Kekerasan terhadap Perempuan Meningkat: Kebijakan Penghapusan Kekerasan Seksual Menciptakan Ruang Aman Bagi perempuan dan anak perempuan. Catatan Kekerasan Terhadap Perempuan Tahun 2019. Komnasperempuan. Retrieved from https://komnasperempuan.go.id/catatan-tahunan-detail/catahu-2020-kekerasanterhadap-perempuan-meningkat-kebijakan-penghapusan-kekerasan-seksualmenciptakan-ruang-aman-bagi-perempuan-dan-anak-perempuan-catatankekerasan-terhadap-perempuan-tahun-2019

Lickona, T. (2009). Educating for character: How our schools can teach respect and responsibility. Bantam. 
Mungmachon, M. R. (2012). Knowledge and Local Wisdom: Community Treasure. International Journal of Humanities and Social Science, 2(13), 174-181.

Samsiyah, N. (2019). Internalisasi Literasi Sastra Berbasis Kearifan Lokal Untuk Menanamkan Karakter Siswa Sd. Konferensi Nasional Bahasa Dan Sastra V, 204208. Retrieved from https://jurnal.fkip.uns.ac.id/index.php/knbs/article/view/12892

Sanjaya, W. (2010). Perencanaan dan Sistem Desain Pembelajaran. Jakarta: Kencana. Sjarkawi, M. P. (2020). Pembentukan kepribadian anak.

Syamsiyah, N. (2020). Pembelajaran daring masa pandemi corona (kegiatan belajar di rumah dalam group kelas 4 mi as-salam). IBTIDA': Media Komunikasi Hasil Penelitian Pendidikan Guru Madrasah Ibtidaiyah, 01(02), 115-125.

Thomas, K. (2004). Learning taxonomies in the cognitive, affective and psychomotor domain. Rocky Mountain Alchemy.

Tomkins, G. E., \& Hoskisson, K. (1991). Teaching Writing Process and Product. New York: Mc Milan College Publishing Company.

Yusa, I. M. M., \& Jayanegara, I. N. (2014). Pengembangan aplikasi penyampaian kearifan lokal melalui cerita rakyat Bali untuk anak sekolah dasar berbasis mobile. Jurnal S@CiesVol 5 No 1, 5. 